\title{
SYNTHESIS, STRUCTURAL CHARACTERIZATION AND CATALYTIC OXIDATION PROPERTY OF SCHIFF BASE COPPER(II) COMPLEXES
}

\author{
SHUANG HAN ${ }^{a, *}$, YUAN WANG ${ }^{b}$ \\ ${ }^{a}$ College of Chemistry and Chemical Engineering, Qiqihar University, Qiqihar 161006, P. R. China \\ ${ }^{b}$ Qiqihar Environmental Monitoring Central Station, Qiqihar 161005, P. R. China
}

\begin{abstract}
Two new square planar mononuclear copper(II) complexes, [CuL $\left.{ }^{1}\right](\mathbf{1})$ and $\left[\mathrm{CuL}^{2}(\mathrm{NCS})\right](\mathbf{2})$, where $\mathrm{L}^{1}$ is the dianionic form of the bis-Schiff base $N, N^{\prime}$ bis(2-hydroxynaphthylmethylidene)-1,3-pentanediamine $\left(\mathrm{H}_{2} \mathrm{~L}^{1}\right)$, and $\mathrm{L}^{2}$ is the monoanionic form of 1-[(2-diethylaminoethylimino)methyl]naphthalen-2-ol (HL $\left.{ }^{2}\right)$, have been synthesized and characterized by physico-chemical methods and single-crystal X-ray diffraction. Complex $(\mathbf{1})\left(\mathrm{C}_{27} \mathrm{H}_{24} \mathrm{CuN}_{2} \mathrm{O}_{2}\right)$ crystallizes as the orthorhombic space group Pbca, with unit cell dimensions $a=18.284(1) \AA, b=12.2373(7) \AA, c=19.775(1) \AA, \mathrm{V}=4424.6(4) \AA^{24}, \mathrm{Z}=8, R_{1}=0.0421, w R_{2}=$ $0.0975, S=1.054$. Complex (2) $\left(\mathrm{C}_{18} \mathrm{H}_{21} \mathrm{CuN}_{3} \mathrm{OS}\right)$ crystallizes as the monoclinic space group $P 2_{1} / c$, with unit cell dimensions $a=12.776(1) \AA, b=24.181(2) \AA, c$ $=11.743(1) \AA, \beta=98.621(1)^{\circ}, \mathrm{V}=3586.7(7) \AA^{3}, \mathrm{Z}=8, R_{1}=0.0520, w R_{2}=0.1183, S=1.012 . \mathrm{X}$-ray analysis indicates that the $\mathrm{Cu}$ atoms in the complexes are in square planar coordination. The complexes were evaluated for their catalytic oxidation of cyclooctene and styrene with tert-butylhydroperoxide.
\end{abstract}

Keywords: Schiff base; copper complex; crystal structure; catalytic property.

\section{INTRODUCTION}

The oxidation of various hydrocarbons catalyzed by metal complexes with various ligands has received particular attention over the last few years. ${ }^{1-4}$ Copper(II) complexes have been proved to possess excellent catalytic activity towards a number of organic reactions..$^{5-8}$ In particular, copper complexes derived from Schiff bases are amongst the most versatile catalysts known for oxygenation reactions. ${ }^{9-11}$ The role played by copper ions in the active sites of a large number of metalloproteins has stimulated efforts to design and characterize copper complexes as models for a better understanding of biological systems. In this paper, two new copper(II) complexes, $\left[\mathrm{CuL}^{1}\right]$ (1) and $\left[\mathrm{CuL}^{2}(\mathrm{NCS})\right](2)$, where $\mathrm{L}^{1}$ is the dianionic form of the bis-Schiff base $N, N^{\prime}$-bis(2-hydroxynaphthylmethylidene)-1,3-pentanediamine $\left(\mathrm{H}_{2} \mathrm{~L}^{1}\right.$; Scheme $1)$, and $\mathrm{L}^{2}$ is the monoanionic form of 1-[(2-diethylaminoethylimino)methyl] naphthalen-2-ol ( $\mathrm{HL}^{2}$; Scheme 1), were prepared and studied their catalytic oxidation of cyclooctene and styrene with tert-butylhydroperoxide (TBHP).<smiles>CCC(CCN=Cc1c(O)ccc2ccccc12)N=Cc1c(O)ccc2ccccc12</smiles>

$\mathrm{H}_{2} \mathrm{~L}^{1}$

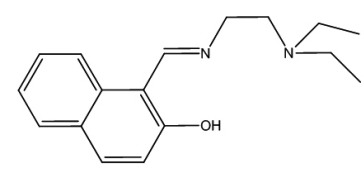

$\mathrm{HL}^{2}$
Scheme 1: The Schiff bases.

\section{EXPERIMENTAL}

General Methods and Materials: Copper perchlorate, 2-hydroxy-1naphthyaldehyde, pentane-1,3-diamine, and $N, N$-diethylethane-1,2-diamine were purchased Lancaster and used as received. All other reagents were of analytical reagent grade. Elemental analyses of $\mathrm{C}, \mathrm{H}$ and $\mathrm{N}$ were carried out in a 2400 Series-II CHN analyzer. FT-IR spectra were obtained on a Jasco FT/IR-4000 spectrometer with samples prepared as $\mathrm{KBr}$ pellets. ${ }^{1} \mathrm{H}$ NMR spectra in DMSO- $d_{6}$ were run in a Bruker AMX 300 instrument, using TMS as internal reference. Gas chromatography analysis was performed with an Agilent Technologies $6890 \mathrm{~N}$ network GC system equipped with a fused silica capillary column $(30 \mathrm{~m} \times 0.32 \mathrm{~mm})$ and a FID detector. Molar conductance was measured with a Shanghai DDS-11A conductometer. X-ray diffraction was carried out on a Bruker SMART 1000 CCD diffractometer.

Caution: Copper perchlorate is potentially explosive, only small quantity should be used and handled with great care.

Synthesis of the Schiff Bases: The Schiff bases were synthesized as follows. To the methanolic solution $(30 \mathrm{~mL})$ of 2-hydroxy-1-naphthyaldehyde $(2.0 \mathrm{mmol}, 0.34 \mathrm{~g})$ was added a methanolic solution $(30 \mathrm{~mL})$ of pentane-1,3diamine (1.0 mmol, $0.10 \mathrm{~g})$ or $N, N$-diethylethane-1,2-diamine (2.0 mmol, 0.23 g) with stirring. The mixtures were stirred for $30 \mathrm{~min}$ at room temperature to give yellow solution. The solvent was evaporated to give yellow precipitate or gummy product, which was dried by $\mathrm{P}_{2} \mathrm{O}_{5}$.

For $\mathrm{H}_{2} \mathrm{~L}^{1}$ : Yield $93 \%$. Characteristic IR data $\left(\mathrm{cm}^{-1}\right): 3332(\mathrm{~m}), 1633(\mathrm{~s})$, 1231 (m). Anal. Calc. for $\mathrm{C}_{27} \mathrm{H}_{26} \mathrm{~N}_{2} \mathrm{O}_{2}: \mathrm{C}, 79.0 ; \mathrm{H}, 6.4 ; \mathrm{N}, 6.8$. Found: $\mathrm{C}, 78.8$; $\mathrm{H}, 6.5 ; \mathrm{N}, 6.8 \%$. ${ }^{1} \mathrm{HNMR}$ data $\left(\mathrm{CDCl}_{3}, \mathrm{ppm}\right): \delta=0.91(\mathrm{t}, 3 \mathrm{H}), 1.65(\mathrm{~m}, 2 \mathrm{H})$, $1.96(\mathrm{~m}, 2 \mathrm{H}), 3.09(\mathrm{~m}, 1 \mathrm{H}), 3.57(\mathrm{t}, 2 \mathrm{H}), 7.20-8.10(\mathrm{~m}, 12 \mathrm{H}), 8.75(\mathrm{~s}, 1 \mathrm{H})$, $8.80(\mathrm{~s}, 1 \mathrm{H}), 12.2(\mathrm{~d}, 2 \mathrm{H})$. For $\mathrm{HL}^{2}$ : Yield $87 \%$. Characteristic IR data $\left(\mathrm{cm}^{-1}\right)$ : $3381(\mathrm{~m}), 1629$ (s), 1227 (m). Anal. Calc. for $\mathrm{C}_{17} \mathrm{H}_{22} \mathrm{~N}_{2} \mathrm{O}: \mathrm{C}, 75.5 ; \mathrm{H}, 8.2 ; \mathrm{N}$, 10.4. Found: $\mathrm{C}, 75.6 ; \mathrm{H}, 8.1 ; \mathrm{N}, 10.5 \%$. ${ }^{1} \mathrm{HNMR}$ data $\left(\mathrm{CDCl}_{3}, \mathrm{ppm}\right): \delta=1.03$ $(\mathrm{t}, 6 \mathrm{H}), 2.75(\mathrm{t}, 2 \mathrm{H}), 2.99(\mathrm{t}, 4 \mathrm{H}), 3.66(\mathrm{t}, 2 \mathrm{H}), 7.20-8.10(\mathrm{~m}, 6 \mathrm{H}), 8.67(\mathrm{~s}, 1 \mathrm{H})$, $11.8(\mathrm{~s}, 1 \mathrm{H})$

Synthesis of Complex (1): $\mathrm{H}_{2} \mathrm{~L}^{1}(82.0 \mathrm{mg}, 0.2 \mathrm{mmol})$ and copper perchlorate $(75.0 \mathrm{mg}, 0.2 \mathrm{mmol})$ were mixed in methanol $(30 \mathrm{~mL})$. The mixture was refluxed for $2 \mathrm{~h}$ and then cooled to room temperature, and filtered. The filtrate was kept at ambient temperature. Single crystals of the complex, suitable for $\mathrm{X}$-ray diffraction, were grown from the filtrate upon slow evaporation within a few days. The crystals were isolated by filtration, washed with methanol and dried in air. Yield $61 \%$. Characteristic IR data $\left(\mathrm{cm}^{-1}\right): 1617(\mathrm{~s}), 1183(\mathrm{~m})$. Anal. Calc. for $\mathrm{C}_{27} \mathrm{H}_{24} \mathrm{CuN}_{2} \mathrm{O}_{2}: \mathrm{C}, 68.7 ; \mathrm{H}, 5.1 ; \mathrm{N}, 5.9$. Found: $\mathrm{C}, 68.6 ; \mathrm{H}, 5.2 ; \mathrm{N}$, $5.8 \%$.

Synthesis of Complex (2): $\mathrm{HL}^{2}(54.0 \mathrm{mg}, 0.2 \mathrm{mmol})$, ammonium thiocyanate and copper perchlorate $(75.0 \mathrm{mg}, 0.2 \mathrm{mmol})$ were mixed in methanol $(30 \mathrm{~mL})$. The mixture was refluxed for $2 \mathrm{~h}$ and then cooled to room temperature, and filtered. The filtrate was kept at ambient temperature. Single crystals of the complex, suitable for X-ray diffraction, were grown from the filtrate upon slow evaporation within a few days. The crystals were isolated by filtration, washed with methanol and dried in air. Yield 53\%. Characteristic IR data $\left(\mathrm{cm}^{-1}\right): 2091$ (s), $1620(\mathrm{~s}), 1185(\mathrm{~m})$. Anal. Calc. for $\mathrm{C}_{18} \mathrm{H}_{21} \mathrm{CuN}_{3} \mathrm{OS}$ : C, 55.3; H, 5.4; N, 10.7 . Found: C, 55.4; $\mathrm{H}, 5.4 ; \mathrm{N}, 10.9 \%$.

X-ray Crystallography: Single-crystal X-ray diffraction data for the complexes were collected on a Bruker Smart 1000 CCD diffractometer at $298(2) \mathrm{K}$ with Mo K $\alpha$ radiation $(\lambda=0.71073 \AA)$ by $\omega$ scan mode. The program SAINT $^{12}$ was used for integration of the diffraction profiles. Structures were solved by direct methods using the SHELXS program of the SHELXTL package and refined by full-matrix least-squares methods with SHELXL (semi-empirical absorption corrections were applied using the SADABS program) ${ }^{13,14}$ The positions of the non-hydrogen atoms were located in difference Fourier syntheses and least-squares refinement cycles, and finally refined anisotropically. The hydrogen atoms of the complexes were placed theoretically onto the specific atoms and refined isotropically as riding atoms. Crystallographic data and experimental details for structural analyses are summarized in Table 1. Selected bond lengths and angles for the complexes are listed in Table 2. 
Table 1 Crystallographic information for the complexes

\begin{tabular}{|c|c|c|}
\hline Complex & (1) & (2) \\
\hline Formula & $\mathrm{C}_{27} \mathrm{H}_{24} \mathrm{CuN}_{2} \mathrm{O}_{2}$ & $\mathrm{C}_{18} \mathrm{H}_{21} \mathrm{CuN}_{3} \mathrm{OS}$ \\
\hline Formula weight & 472.0 & 391.0 \\
\hline Crystal shape/color & Block/blue & Block/blue \\
\hline$T(\mathrm{~K})$ & $298(2)$ & $298(2)$ \\
\hline Crystal dimensions $\left(\mathrm{mm}^{3}\right)$ & $0.17 \times 0.15 \times 0.15$ & $0.25 \times 0.10 \times 0.05$ \\
\hline Crystal system & Orthorhombic & Monoclinic \\
\hline Space group & $P b c a$ & $P 2_{1} / c$ \\
\hline$a(\AA)$ & $18.284(1)$ & $12.776(1)$ \\
\hline$b(\AA)$ & $12.2373(7)$ & $24.181(2)$ \\
\hline$c(\AA)$ & $19.775(1)$ & $11.743(1)$ \\
\hline$\beta\left({ }^{\circ}\right)$ & 90 & $98.621(1)$ \\
\hline$V\left(\AA^{3}\right)$ & $4424.6(4)$ & $3586.7(7)$ \\
\hline$Z$ & 8 & 8 \\
\hline$D_{\text {calc }}\left(\mathrm{g} \mathrm{cm}^{-3}\right)$ & 1.417 & 1.448 \\
\hline$\mu(\mathrm{Mo} \mathrm{K} \alpha)\left(\mathrm{mm}^{-1}\right)$ & 1.014 & 1.343 \\
\hline$F(000)$ & 1960 & 1624 \\
\hline Measured reflections & 41607 & 30404 \\
\hline Unique reflections & 4112 & 8190 \\
\hline $\begin{array}{l}\text { Observed reflections }(I \geq \\
2 \sigma(I))\end{array}$ & 3089 & 5575 \\
\hline Min. and max. transmission & 0.8465 and 0.8627 & 0.7300 and 0.9359 \\
\hline Parameters & 290 & 437 \\
\hline Goodness of fit on $F^{2}$ & 1.054 & 1.012 \\
\hline$R_{1}, w R_{2}[I \geq 2 \sigma(I)]^{a}$ & $0.0421,0.0975$ & $0.0520,0.1183$ \\
\hline$R_{1}, w R_{2}$ (all data) $^{a}$ & $0.0651,0.1084$ & $0.0849,0.1348$ \\
\hline
\end{tabular}

${ }^{a} R_{1}=F_{o}-F_{c} / F_{o}, w R_{2}=\left[\AA a ̊ ~ w\left(F_{o}^{2}-F c^{2}\right) / a ̊ ~ w\left(F_{o}^{2}\right)^{2}\right]^{1 / 2}$

Table 2 Selected bond lengths $(\AA)$ and angles $\left(^{\circ}\right)$ for the complexes with estimated standard deviations (e.s.d.s) in parentheses

\begin{tabular}{|c|c|c|c|}
\hline$(1)$ & & & \\
\hline $\mathrm{Cu} 1-\mathrm{O} 1$ & $1.8968(19)$ & $\mathrm{Cu} 1-\mathrm{O} 2$ & $1.893(2)$ \\
\hline $\mathrm{Cu} 1-\mathrm{N} 1$ & $1.934(2)$ & $\mathrm{Cu} 1-\mathrm{N} 2$ & $1.940(2)$ \\
\hline O2-Cu1-O1 & $88.67(8)$ & O2-Cu1-N1 & $159.26(10)$ \\
\hline O1-Cu1-N1 & $92.39(9)$ & O2-Cu1-N2 & $91.77(9)$ \\
\hline O1-Cu1-N2 & $154.13(10)$ & N1-Cu1-N2 & $96.17(10)$ \\
\hline$(2)$ & & & \\
\hline $\mathrm{Cu} 1-\mathrm{O} 2$ & $1.908(2)$ & $\mathrm{Cu} 1-\mathrm{N} 4$ & $1.914(3)$ \\
\hline $\mathrm{Cu} 1-\mathrm{N} 5$ & $2.105(3)$ & $\mathrm{Cu} 1-\mathrm{N} 6$ & $1.943(3)$ \\
\hline $\mathrm{Cu} 2-\mathrm{O} 1$ & $1.909(3)$ & $\mathrm{Cu} 2-\mathrm{N} 1$ & $1.915(3)$ \\
\hline $\mathrm{Cu} 2-\mathrm{N} 2$ & $2.113(3)$ & $\mathrm{Cu} 2-\mathrm{N} 3$ & $1.933(3)$ \\
\hline O2-Cu1-N4 & $91.24(10)$ & O2-Cu1-N6 & $89.73(12)$ \\
\hline N4-Cu1-N6 & $177.75(14)$ & O2-Cu1-N5 & $172.32(11)$ \\
\hline N4-Cu1-N5 & $84.84(11)$ & N6-Cu1-N5 & $93.96(12)$ \\
\hline O1-Cu2-N1 & $91.77(12)$ & O1-Cu2-N3 & $87.36(12)$ \\
\hline N1-Cu2-N3 & $175.11(14)$ & O1-Cu2-N2 & $174.49(12)$ \\
\hline N1-Cu2-N2 & $85.14(12)$ & N3-Cu2-N2 & $95.34(13)$ \\
\hline
\end{tabular}

Catalytic Oxidation Procedure: The complexes $(0.032 \mathrm{mmol})$ were dissolved in $10 \mathrm{~mL}$ chloroform in a $50 \mathrm{~mL}$ round bottom flask equipped with a condenser. Then, alkene (cyclooctene or styrene) $(10 \mathrm{mmol})$ and TBHP (30 mmol) were added, respectively. The mixture was refluxed for $6 \mathrm{~h}$. Samples were taken at periodic time intervals and analyzed by gas chromatography. The oxidation products were identified by comparison with authentic samples.

\section{RESULTS AND DISCUSSION}

Synthesis and Characterization: Both complexes (1) and (2) were first synthesized by the reaction of the Schiff base ligand, ammonium thiocyanate and copper perchlorate in methanol. Yet, the thiocyanate anion was not coordinate to the $\mathrm{Cu}$ atom of complex (1). The same product of complex (1) can also be prepared by the reaction of $\mathrm{H}_{2} \mathrm{~L}^{1}$ and copper perchlorate in the absent of ammonium thiocyanate. Elemental analyses of the complexes are in accordance with the molecular structures proposed by the X-ray analysis. FT-IR spectra of both complexes are of similar type, except the existence of intense absorption at $2091 \mathrm{~cm}^{-1}$ of the thiocyanate ligand of complex (2). The complexes show typical $\mathrm{C}=\mathrm{N}$ absorptions at about $1620 \mathrm{~cm}^{-1}$, and typical Ar-O absorptions at about $1185 \mathrm{~cm}^{-1}$. Both complexes are stable in air at room temperature. The molar conductivity of the complexes measured in acetonitrile at concentration of $10^{-3} \mathrm{M}$ are $21.5 \Omega^{-1} \mathrm{~cm}^{2} \mathrm{~mol}^{-1}$ for $(\mathbf{1})$ and $25.0 \Omega^{-1} \mathrm{~cm}^{2} \mathrm{~mol}^{-1}$ for (2), indicating the non-electrolytic nature of the complexes in acetonitrile [15].

Structure Description of the Complexes: The molecular structures of complexes (1) and (2) are shown in Figures 1 and 2, respectively. There are two independent molecules in the asymmetric unit of complex (2). In each of the complexes, the coordination sphere has a tetrahedrally distorted square planar geometry. The four coordinate atoms come from the phenolate $\mathrm{O}$ and imino $\mathrm{N}$ atoms of $\mathrm{L}^{1}$ for (1), and the phenolate $\mathrm{O}$, imino $\mathrm{N}$ and amino $\mathrm{N}$ atoms of $\mathrm{L}^{2}$, and thiocyanate $\mathrm{N}$ atom for (2). The distortion of the square planar geometry can be observed from the bond values. The $\mathrm{Cu}-\mathrm{O} / \mathrm{N}$ bonds are within normal values and comparable to those observed in similar copper complexes. ${ }^{16,17}$ The cis and trans angles vary between $88.67(8)$ and $96.17(10)^{\circ}$, and $154.13(10)$ and $159.26(10)^{\circ}$ for complex (1), and between 84.83(11) and 95.34(13) ${ }^{\circ}$, and $172.32(11)$ and $177.75(14)^{\circ}$ for complex (2), respectively. In complex (1), the dihedral angle between the two naphthyl rings is $47.4(5)^{\circ}$.

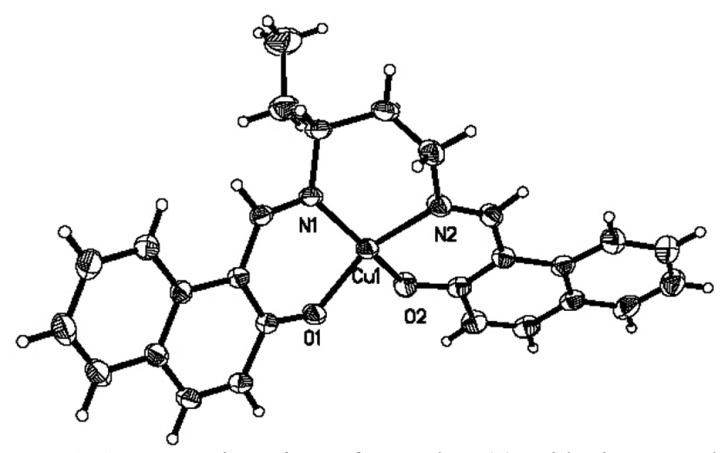

Figure 1 A perspective view of complex (1) with the atom labeling scheme. Thermal ellipsoids are drawn at the $30 \%$ probability level.

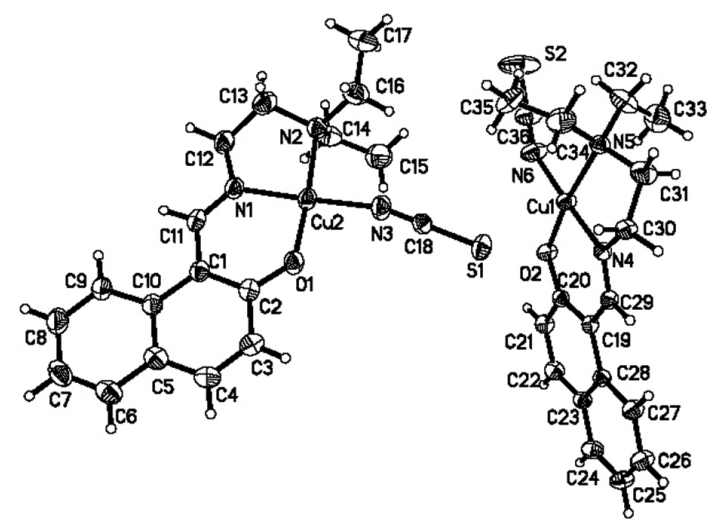

Figure 2 A perspective view of complex (2) with the atom labeling scheme. Thermal ellipsoids are drawn at the $30 \%$ probability level. 
Table 3 Catalytic oxidation results of the complexes in acetonitrile $\mathrm{e}^{\mathrm{a}}$

\begin{tabular}{|c|c|c|c|c|}
\hline \multirow{2}{*}{ Complex } & \multirow{2}{*}{ Conversion } & \multirow{2}{*}{ TON $^{\mathrm{b}}$} & \multicolumn{2}{|c|}{ Product selectivity (\%) } \\
\cline { 4 - 5 } & & & Styrene oxide & Benzaldehyde \\
\hline$(\mathbf{1})$ & $99 \%$ & 289 & 28 & 54 \\
\hline$(2)$ & $93 \%$ & 273 & 23 & 67 \\
\hline
\end{tabular}

a Solvent: $10 \mathrm{~mL}$; catalyst: $0.032 \mathrm{mmol}$; Styrene: $(1.04 \mathrm{~g}, 10 \mathrm{mmol})$; TBHP: $30 \mathrm{mmol}$.

${ }^{\mathrm{b}}$ TON: (turnover number) moles of substrate converted per mole of copper ion.

Catalytic Oxidation Results: Selective oxidation of cyclooctene to cyclooctene oxide, catalyzed by the complexes, was carried out using TBHP as oxidant. The effect of different parameters such as the oxidant to alkene molar ratio and the nature of solvent were investigated.

It was observed that the change of TBHP/cyclooctene molar ratio from $1: 1$ to $3: 1$ increases the conversion from $51 \%$ to $72 \%$ for complex (1) and from $39 \%$ to $47 \%$ for complex (2). Addition of excess amounts of oxidant over 3:1 ratio has little effect on cyclooctene conversion. In order to investigate the effect of solvent, chloroform, dichloromethane and acetonitrile have been used and the highest conversion (68\% for (1) and $45 \%$ for (2)) was obtained in acetonitrile.

Catalytic oxidation of styrene with TBHP in the presence of the complexes gave benzaldehyde as major product along with moderately low yields of styrene oxide (Table 3). In order to obtain the best oxidant/styrene molar ratio, three different TBHP/styrene molar ratios $(1: 1,2: 1$ and 3:1) were considered. A maximum of $99 \%$ conversion for complex (1) and $93 \%$ for complex (2) was obtained at the $3: 1$ molar ratio in acetonitrile.

\section{CONCLUSION}

The present study reports the synthesis, characterization and crystal structures of two new mononuclear copper(II) complexes with Schiff bases. The complexes have efficient catalytic oxidation properties on alkenes with TBHP as oxidant.

\section{APPENDIX A. SUPPLEMENTARY DATA}

CCDC 892373 (1) and 614321 (2) contain the supplementary crystallographic data for this paper. These data can be obtained free of charge via http://www.ccdc.cam.ac.uk/conts/retrieving.html, or from the Cambridge Crystallographic Data Centre, 12 Union Road, Cambridge CB2 1EZ, UK; fax: (+44) 1223-336-033; or e-mail: deposit@ccdc.cam.ac.uk.

\section{ACKNOWLEDGMENTS}

This work was financially supported by the Program for Young Teachers Scientific Research in Qiqihar University (2012k-M05), and the Education Office of Heilongjiang Province (Project No. 12531757).

\section{REFERENCES}

1. M. Debnath, A. Dutta, S. Biswas, K.K. Das, H.M. Lee, J. Vicha, R. Marek, J. Marek, M. Ali, Polyhedron 63, 189, (2013).

2. M.L. Shilpa, V. Gayathri, Transition Met. Chem. 38, 705, (2013).

3. M. Ghorbanloo, M. Jaworska, P. Paluch, G.-D. Li, L.-J. Zhou, Transition Met. Chem. 38, 511, (2013).

4. G. Romanowski, J. Kira, Polyhedron 53, 172, (2013).

5. A. Soroceanu, M. Cazacu, S. Shova, C. Turta, J. Kozisek, M. Gall, M. Breza, P. Rapta, T.C.O. Mac Leod, A.J.L. Pombeiro, J. Telser, A.A. Dobrov, V.B. Arion, Eur. J. Inorg. Chem. 9, 1458, (2013).

6. R. Kumar, K. Mahiya, P. Mathur, Dalton Trans. 42, 8553, (2013).

7. I. Gamba, I. Mutikainen, E. Bouwman, J. Reedijk, S. Bonnet, Eur. J. Inorg. Chem. 1, 115, (2013).

8. M.N. Kopylovich, A. Mizar, M.F.C.G. da Silva, T.C.O. Mac Leod, K.T. Mahmudov, A.J.L. Pombeiro, Chem. Eur. J. 19, 587, (2013).

9. A. Ourari, D. Aggoun, L. Ouahab, Inorg. Chem. Commun. 33, 118, (2013).

10. M.A. Ali, P.V. Bernhardt, M.A.H. Brax, J. England, A.J. Farlow, G.R. Hanson, L.L. Yeng, A.H. Mirza, K. Wieghardt, Inorg. Chem. 52, 1650, (2013).

11. F. Heshmatpour, S. Rayati, M.A. Hajiabbas, P. Abdolalian, B. Neumuller, Polyhedron 31, 443, (2012).
12. Bruker AXS, SAINT Software Reference Manual, Madison, WI, (1998).

13. G.M. Sheldrick, SADABS, Siemens Area Detector Absorption Corrected Software, University of Göttingen, Germany, (1996).

14. G.M. Sheldrick, SHELXTL NT Version 5.1. Program for Solution and Refinement of Crystal Structures, University of Göttingen, Germany, (1997).

15. W.J. Geary, Coord. Chem. Rev. 7, 81, (1971).

16. S. Rayati, S. Zakavi, M. Koliaei, A. Wojtczak, A. Kozakiewicz, Inorg. Chem. Commun. 13, 203, (2010).

17. S. Naiya, C. Biswas, M.G.B. Drew, C.J. Gomez-Garcia, J.M. ClementeJuan, A. Ghosh, Inorg. Chem. 49, 6616, (2010). 